\title{
EDUCATION
}

\section{4-2015 Clinical Laboratory Science Faculty Salary Survey}

\section{PERRY SCANLAN, PETER HU}

\section{ABSTRACT}

OBJECTIVES: The objective was to report faculty salary and benefit information for professionals in clinical laboratory science.

METHODS: Salary data from the 2014-2015 academic year were collected using an electronic survey through Baseline (Campus Labs), a survey tool used with a web interface at Austin Peay State University. Survey respondents were recruited via email and included members of the American Society of Clinical Laboratory Science, subscribers to the Clinical Laboratory Science Educator's listserv, and members of the programs accredited by the National Accreditation Agency for Clinical Laboratory Sciences. Salary data were sorted by certification, highest degree earned, position title or academic rank, and employer type. Statistical analysis was performed and data reported as mean, standard error of the mean, 95\% confidence intervals, and relative error of the mean.

RESULTS: The average salary of certified medical laboratory scientist (MLS)/medical technologist (MT) faculty increased from $\$ 61,823.44$ for those with bachelor's degrees to $\$ 99,321.35$ for those with doctoral degrees. Those with molecular biology certification had average salaries of $\$ 87,200.00$ for respondents with master's degrees and $\$ 96,495.83$ for respondents with doctoral degrees. The average total annual salary for MLS/MT faculty was $\$ 64,239.96$ for full-time instructors/adjuncts/ lecturers and $\$ 104,620.00$ for full professors. Salaries at university hospitals were substantially larger than those at community colleges.

CONCLUSIONS: This study, the first to examine the faculty salaries of clinical laboratory scientists, provides new, publically available information about faculty salaries in clinical laboratory science. This information can be used by policy makers and clinical professionals to gauge fair and competitive market salaries and set promotional structures. Previously, such data have been available only by subscription and at prices that only larger institutions can afford.

ABBREVIATIONS: MLT - medical laboratory technician, MLS - medical laboratory scientist, CIP Classification of Instructional Programs, ASCLS American Society for Clinical Laboratory Science, NAACLS - National Accreditation Agency for Clinical Laboratory Sciences, MLS(ASCP) ${ }^{\mathrm{CM}}$ - MLS credentialed by the American Society for Clinical Pathology, MT(ASCP) - medical technologist credentialed by the American Society for Clinical Pathology prior to October 22, 2009, MT(AMT) medical technologist credentialed by American Medical Technologists, USD - U.S. dollars, SD standard deviation, SEM - standard error of the mean, REM - relative error of the mean, SBB - Specialist in Blood Banking, SH - Specialist in Hematology, SM Specialist in Microbiology, SC - Specialist in Chemistry , DLM - Diplomate in Laboratory Management .

INDEX TERMS: Faculty, Salaries and Fringe Benefits, Medical Laboratory Science

Clin Lab Sci 2016;29(2):72-91

Perry M. Scanlan Ph.D., MT(ASCP), Department of Allied Health Sciences, Austin Peay State University, Clarksville, TN

Peter Hu, PhD, MS, MLS(ASCP) ${ }^{C M}, C G^{C M}, M B^{C M}$ School of Health Professions, The University of Texas MD Anderson Cancer Center, Houston, TX

Address for Correspondence: Perry M. Scanlan Ph.D., MT(ASCP), Department of Allied Health Sciences P.O. Box 4668, Austin Peay State University, Clarksville, TN 37044

\section{INTRODUCTION}

Laboratory medicine professionals include individuals 
with experience in medical laboratory science, cytology, histotechnology, molecular genetics, pathology, and/or other areas. These professionals' different education levels add another layer of complexity to the types of jobs they possess and the scope of practice they each perform. Historically, in studies assessing trends in these professionals' jobs and related factors, each laboratory medicine subsection has been separated into specialty groups, which have been surveyed to assess their practice scopes, ${ }^{1}$ vacancy rates, ${ }^{2}$ and salary information. ${ }^{2}$ However, unlike other health science fields, laboratory medicine includes different positions whose specific scopes of practice differ based on the individual's degree and certification. For example, the difference between a veterinary technician and veterinary technologist, or between a radiologic technician and radiologic technologist, or between a registered nurse with an associate's degree and one with a bachelor's degree is a bachelor's degree, not specific program content. ${ }^{3-5}$ This is not the case in medical laboratory science, in which medical laboratory technicians (MLTs) and medical laboratory scientists (MLSs) have distinct scopes of practice within their accreditation requirements. ${ }^{6,7}$

Because the majority of laboratory medicine professionals perform daily bench or supervisory work, most studies of salary compensation in this group report statistical data regarding the job titles and salary information of these professionals. ${ }^{2,8} \mathrm{~A}$ few previous studies of allied health science educators and their salaries were based on published data from the Association of Schools of Allied Health Professions, ${ }^{9}$ but those data were collected from and are available to the association's member institutions only. The College and University Professional Association for Human Resources also publishes salary data by Classification of Instructional Programs (CIP) code, but only the two-digit codes, which are inclusive of health professions and related programs (Table 1), are freely available to the public; the 4- (51.10) or 6-digit codes must be purchased. ${ }^{10,11}$ Although using 2- or even 4-digit CIP codes when analyzing the salary data of laboratory medicine professionals may facilitate the detection of statistically significant differences among subpopulations in this group, doing so may present some real problems. As shown in Table 1 , the positions identified by even the same CIP codes vary widely; thus, using the codes to analyze salary data could result in the grouping of levels of practice that should not be considered together (e.g., phlebotomy, MLT, and MLS) or worse, the grouping of positions that require very different skill sets (e.g., renal dialysis technicians and technologists with MLS certification).

Table 1. 2010 Classification of Instructional Programs 2-Digit and 4-Digit CIP Codes. ${ }^{11}$ Table taken from CUPA-HR (used with permission) Available at http://www.cupahr.org/surveys/files/salary2015/FHE4-15-2-4-CIP-Codes.xls

\begin{tabular}{|c|c|c|}
\hline$[51 . \mathrm{XX}]$ & $\begin{array}{l}\text { Health Professions and } \\
\text { Related Clinical Sciences }\end{array}$ & \\
\hline [51.00] & $\begin{array}{l}\text { Health Services/Allied } \\
\text { Health/Health Sciences, } \\
\text { General }\end{array}$ & $\begin{array}{l}\text { A general, introductory, undifferentiated, or joint program in health } \\
\text { services occupations that prepares individuals for either entry into } \\
\text { specialized training programs or for a variety of concentrations in the allied } \\
\text { health area. }\end{array}$ \\
\hline [51.01] & Chiropractic & $\begin{array}{l}\text { A program that prepares individuals for the independent professional } \\
\text { practice of chiropractic, a health care and healing system based on the } \\
\text { application of non-invasive treatments and spinal adjustments to alleviate } \\
\text { health problems caused by vertebral misalignments affecting bodily } \\
\text { function. }\end{array}$ \\
\hline [51.02] & $\begin{array}{l}\text { Communication } \\
\text { Disorders Sciences and } \\
\text { Services }\end{array}$ & $\begin{array}{l}\text { Communications Disorders - General and Other, Audiology/Audiologist } \\
\text { and Hearing Sciences, Speech-Language Pathology/Pathologist, } \\
\text { Audiology/Audiologist and Speech-Language Pathology/Pathologist }\end{array}$ \\
\hline [51.04] & Dentistry & $\begin{array}{l}\text { A program that prepares individuals for the independent professional } \\
\text { practice of dentistry/dental medicine, encompassing the evaluation, } \\
\text { diagnosis, prevention, and treatment of diseases, disorders, and conditions } \\
\text { of the oral cavity, maxiofacial area, and adjacent structures and their impact } \\
\text { on the human body and health. }\end{array}$ \\
\hline [51.05] & $\begin{array}{l}\text { Advanced/Graduate } \\
\text { Dentistry and Oral } \\
\text { Sciences }\end{array}$ & $\begin{array}{l}\text { Dental Clinical Sciences, General; Advanced General Dentistry; Oral } \\
\text { Biology and Oral Pathology; Dental Public Health and Education; Dental } \\
\text { Materials; Endodontics/Endodontology; Oral/Maxillofacial Surgery; } \\
\text { Orthodontics/Orthodontology; Pediatric Dentistry/Pedodontics; }\end{array}$ \\
\hline
\end{tabular}




\section{EDUCATION}

Periodontics/Periodontology; Prosthodontics/Prosthodontology; Other

[51.06]

$[51.07]$
Dental Support Services and Allied Professions

Health and Medical Administrative Services

Allied Health and Medical Assisting Services

Allied Health Diagnostic, Intervention, and Treatment Professions

Health/Medical Preparatory Programs

Medicine (MD)

Medical Clinical Sciences/Graduate Medical Studies
Dental Assisting/Assistant, Dental Hygiene/Hygienist, Dental Laboratory Technology/Technician, Other

Health/Health Care Administration/Management, Hospital and Health Care Facilities Administration/Management, Health Unit Coordinator/Ward Clerk, Health Unit Manager/Ward Supervisor, Medical Office Management/Administration, Health Information/Medical Records Administration/Administrator, Health Information/Medical Records Technology/Technician, Medical Transcription/Transcriptionist, Medical Office Computer Specialist/Assistant, Medical Office Assistant/Specialist, Medical Reception/Receptionist, Medical Insurance Coding Specialist/Coder, Medical Insurance Specialist/Medical Biller, Health/Medical Claims Examiner, Medical Administrative/Executive Assistant and Medical Secretary, Medical Staff Services Technology/Technician, Other

Medical/Clinical Assistant, Clinical/Medical Laboratory Assistant, Occupational Therapist Assistant, Pharmacy Technician/Assistant, Physical Therapist Assistant, Veterinary/Animal Health Technology, Anesthesiologist Assistant, Emergency Care Attendant,

Pathology/Pathologist Assistant, Respiratory Therapy Technician/Assistant, Chiropractic Assistant/Technician, Other

Cardiovascular Technology/Technologist, Electrocardiograph Technologist/Technician, Electorneurodiagnostic/Electroencephalographic Technology/Technologist, Emergency Medical Technology/Technician, Nuclear Medicine Technology/Technician, Perfusion Technology/Perfusionist, Medical Radiologic Technology/Science Radiation Therapist, Respiratory Care Therapy/Therapist, Surgical Technology/Technologist, Diagnostic Medical Sonography/Sonographer and Ultrasound, Radiologic Technology/Science - Radiographer, Physician Assistant, Athletic Training/Trainer, Gene/Genetic Therapy,

Cardiopulmonary Technology/Technologist, Radiation Protection/Health Physics Technician, Other

Instructional content for this group of programs is defined in codes 51.1001- 51.1099. 51.1001) Blood Bank Technology Specialist., 51.1002)

Cytotechnology/Cytotechnologist., 51.1003) Hematology

Technology/Technician., 51.1004) Clinical/Medical Laboratory

Technician., 51.1005) Clinical Laboratory Science/Medical

Technology/Technologist., 51.1006) Ophthalmic Laboratory

Technology/Technician., 51.1007) Histologic

Technology/Histotechnologist., 51.1008) Histologic Technician., 51.1009) Phlebotomy Technician/Phlebotomist., 51.1010)

Cytogenetics/Genetics/Clinical Genetics Technology/Technologist., 51.1011) Renal/Dialysis Technologist/Technician., 51.1012) Sterile Processing Technology/Technician., 51.1099) Clinical/Medical Laboratory Science and Allied Professions, Other.

Pre-Dentistry Studies, Pre-Medicine/Pre-Medical Studies, Pre-Pharmacy Studies, Pre-Veterinary Studies, Pre-Nursing Studies, Other

A program that prepares individuals for the independent professional practice of medicine, involving the prevention, diagnosis, and treatment of illnesses, injuries, and other disorders of the human body.

Medical Scientist - An undifferentiated clinical science program that prepares graduated physicians as research scientists in various areas. 


\section{EDUCATION}

[51.15]

[51.16]

[51.17]
Mental and Social Health Services and Allied Professions

Report Nursing
under
51.38
or
51.39

Optometry (OD)

Ophthalmic and Optometric Support Services and Allied

Professions

Osteopathic

Medicine/Osteopathy

Pharmacy, Pharmaceutical

Sciences, and

Administration

Podiatric

Medicine/Podiatry

Public Health

Rehabilitation and Therapeutic Professions

Veterinary Medicine

Veterinary Biomedical and Clinical Sciences

Health Aides/ Attendants/Orderlies Medical Illustration and Informatics
Substance Abuse/Addiction Counseling, Psychiatric/Mental Health Services Technician, Clinical/Medical Social Work, Community Health Services/Liaison/Counseling, Marriage and Family Therapy/Counseling, Clinical Pastoral Counseling/Patient Counseling, Psychoanalysis and Psychotherapy, Mental Health Counseling/Counselor, Genetics Counseling/Counselor, Other

Nursing/Registered Nurse, Nursing Administration, Adult Health Nurse/Nursing, Nurse Anesthetist, Family Practice Nurse/Nurse Practitioner, Maternal/Child Health and Neonatal Nurse/Nursing, Nurse Midwife/Nursing Midwifery, Nursing Science, Pediatric Nurse/Nursing, Psychiatric/Mental Health Nurse/Nursing, Public Health/Community Nurse/Nursing, Perioperative/Operating Room and Surgical Nurse/Nursing, Licensed Practical/Vocational Nurse Training, Nurse/Nursing Assistant/Aide and Patient Care Assistant, Clinical Nurse Specialist, Critical Nurse Specialist, Critical Care Nursing, Occupational and Environmental Health Nursing, Other

A program that prepares individuals for the independent professional practice of optometry and that focuses on the principles and techniques for examining, diagnosing and treating conditions of the visual system. Includes instruction in prescribing glasses and contact lenses, other optical aids, corrective therapies, patient counseling, physician referral, practice management, and ethics and professional standards. Opticianry/Ophthalmic Dispensing Optician, Optometric Technician/Assistant, Ophthalmic Technician/Technologist, Orthoptics/Orthoptist, Other

A program that prepares individuals for the independent professional practice of osteopathic medicine.

Pharmacy; Pharmacy Administration and Pharmacy Policy and Regulatory Affairs; Pharmaceutics and Drug Design; Medicinal and Pharmaceutical Chemistry; Natural Products Chemistry and Pharmacognosy; Clinical and Industrial Drug Development; Pharmaeconomics/Pharmaceutical Economics; Clinical, Hospital, and Managed Care Pharmacy; Industrial and Physical Pharmacy and Cosmetic Sciences; Other

A program that prepares individuals for the independent practice of podiatric medicine.

Public Health - General and Other, Environmental Health, Health/Medical Physics, Occupational Health and Industrial Hygiene, Public Health Education and Promotion, Community Health and Preventative Medicine, Maternal and Child Health, International Public Health/International Health, Health Services Administration Art Therapy/Therapist, Dance Therapy/Therapist, Music Therapy/Therapist, Occupational Therapy/Therapist, Orthotist/Prosthetist, Physical Therapy/Therapist, Therapeutic Recreation/Recreational Therapy, Vocational Rehabilitation Counseling/Counselor, Kinesiotherapy/Kinesiotherapist,

Assistive/Augmentative Technology and Rehabilitation Engineering, Other A program that prepares individuals for the independent practice of veterinary medicine.

Veterinary Sciences/Veterinary Clinical Sciences - General and Other; Veterinary Anatomy; Veterinary Physiology; Veterinary Microbiology and Immunobiology; Veterinary Pathology and Pathobiology; Veterinary Toxicology and Pharmacology; Large Animal/Food Animal and Equine Surgery and Medicine; Small/Companion Animal Surgery and Medicine; Comparative and Laboratory Animal Medicine; Veterinary Preventive Medicine Epidemiology, and Public Health; Veterinary Infectious Diseases Health Aide, Home Health Aide/Home Attendant, Medication Aide, Other

Medical Illustration/Medical Illustrator, Medical Informatics, Other 


\section{EDUCATION}

[51.31]

[51.32]

Dietetics and Clinical

Nutrition Services

Bioethics/Medical Ethics

[51.33]

[51.34]

[51.35]

[51.36]

[51.37]

[51.38]

Alternative and

Complementary Medicine

and Medical Systems

Alternative and

Complementary Medicine

and Medical Support

Services

Somatic Bodywork and

Related Therapeutic

Services

Movement and Mind-

Body Therapies and

Education

Energy and Biologically

Based Therapies

Registered Nursing,

Nursing Administration,

Nursing Research and

Clinical Nursing

[51.39]

\begin{abstract}
New
\end{abstract}
Practical Nursing,

Vocational Nursing and

Nursing Assistants

[51.99]
Dietetics/Dietitian, Clinical Nutrition/Nutritionist, Dietetic Technician, Dietitian Assistant, Other

A program that focuses on the application of ethics, religion, jurisprudence, and the social sciences to the analysis of healthcare issues, clinical decisionmaking, an research procedures.

Acupuncture, Traditional Chinese/Asian Medicine and Chinese

Herbology, Naturopathic Medicine/Naturopathy, Homeopathic

Medicine/Homeopathy, Ayurvedic Medicine/Ayurveda, Other

Direct Entry Midwifery, Other

Massage Therapy/Therapeutic Massage, Asian Bodywork Therapy, Somatic Bodywork, Other

Movement Therapy and Movement Education, Yoga Teacher

Training/Yoga Therapy, Hypnotherapy/Hypnotherapist, Other

Aromatherapy, Herbalism/Herbalist, Polarity Therapy, Reiki, Other

Instructional content for this group of programs is defined in codes 51.3801 - 51.3899. 51.3801: Registered Nursing/Registered Nurse, 51.3802: Nursing Administration, 51.3803: Adult Health Nurse/Nursing, 51.3804: Nurse Anesthetist, 51.3805: Family Practice Nurse/Nursing, 51.3806: Maternal/Child Health and Neonatal Nurse/Nursing, 51.3807:Nurse Midwife/Nursing Midwifery, 51.3808: Nursing Science, 51.3809: Pediatric Nurse/Nursing, 51.3810: Psychiatric/Mental Health Nurse/Nursing, 51.3811: Public Health/Community Nurse/Nursing, 51.3812: Perioperative/Operating Room and Surgical Nurse/Nursing, 51.3813: Clinical Nurse Specialist, 51.3814: Critical Care Nursing,51.3815: Occupational and Environmental Health Nursing, 51.3816: Emergency Room/Trauma Nursing, 51.3817: Nursing Education, 51.3818: Nursing Practice, 51.3819: Palliative Care Nursing, 51.3820: Clinical Nurse Leader, 51.3821: Geriatric Nurse/Nursing, 51.3822: Women's Health Nurse/Nursing, 51.3899: Registered Nursing, Nursing Administration, Nursing Research and Clinical Nursing, Other. Instructional content for this group of programs is defined in codes 51.3901 - 51.3999. 51.3901: Licensed Practical/Vocational Nurse Training, 51.3902: Nursing Assistant/Aide and Patient Care Assistant/Aide, 51.3999: Practical Nursing, Vocational Nursing and Nursing Assistants, Other.

Any instructional program in the health professions and related clinical sciences not listed above.
We conducted a survey of medical laboratory professionals to collect specific data about their salaries and benefits, grouped these data according to respondents' education level, contract duration, and scope of practice, and compared these data across groups. Institutional decision makers will find these data useful when hiring new faculty or establishing promotional structures. There are significant gaps in the current literature regarding faculty wages in the medical laboratory science field. ${ }^{12}$ In addition, overly broad classifications of workers in related fields creates inaccurate salary information that is used by decision makers. This study provides specific salary data for medical laboratory professionals and makes it publically available for employers and job seekers alike. This study will assist in the construction of proper faculty wage and promotion scales at all levels of academic and health institutions.

\section{MATERIALS AND METHODS Respondents and Data Collection}

This salary survey was approved by Austin Peay State University's Institutional Review Board (project \#14043, P.M. Scanlan). We used Baseline (Campus Labs, 


\section{EDUCATION}

Buffalo, NY), a survey collection program, in conjunction with Austin Peay State University, to collect data from respondents who completed the 2014-2015 Clinical Laboratory Science Faculty Salary Survey between September 23, 2014, and February 8, 2015. Potential respondents were recruited via e-mail and included members of the American Society of Clinical Laboratory Science (ASCLS), subscribers to the Clinical Laboratory Science Educator's listserv, and members of the programs accredited by the National Accreditation Agency for Clinical Laboratory Sciences (NAACLS).

Respondents completed the anonymous survey on a secure Web site. The survey included questions about respondents' primary specialties, certifications, laboratories, teaching experience, research experience, education level, salary compensation, extra compensation, job titles, and programs. Many respondents had multiple certifications; such respondents included those who had MLT, MLS, and specialty certifications. For the purposes of this study, MLSs (MLS ${ }^{\mathrm{CM}}$ (ASCP)) credentialed by the American Society for Clinical Pathology, medical technologists (MT (ASCP)) credentialed by the American Society for Clinical Pathology prior to October 22, 2009, and medical technologists (MT (AMT)) credentialed by American Medical Technologists were considered to be equivalent. To accommodate the diversity of positions within the field of clinical laboratory science, respondents could select more than one specialty area. Participants who provided uninterpretable, incomplete, or excessively large or small data were excluded from the study. Not all data are shown to protect the respondents' confidentiality.

Because educators in the field of medical laboratory science are likely to have different types of terminal academic degrees in a variety of related fields, the survey assessed respondents' experience in three areas: duration of clinical laboratory experience, duration of educator experience, and duration of research laboratory experience. The final category was a soft indicator of the type of research respondents conducted (i.e., basic science research or research in other areas, e.g., clinical research, social research). This was done to garner a more accurate assessment of the experience of respondents with faculty positions.

In addition to the range of terminal degrees, the various structures of academic programs present a challenge in conducting salary studies in the clinical laboratory science field. There are a variety of programs in hospital, community college, and university settings. Each type of program uses a variety of titles for its educators, including special titles for clinical coordinators, program directors, and those with other specialized roles. In the present study, the survey respondents were given options that included standard terms such as "Manager/Supervisor," "Full-Time Instructor/Adjunct/Lecturer," "Assistant Professor," "Associate Professor," "Full Professor," and "Dean." In addition, respondents could select "Other" and provide more information about their position titles. Respondents selected what they considered to be their proper titles, which limited bias in coding the collected information. Data reported by respondents in the "Other" category were used in data analysis only when a respondent clearly identified a title that could be easily matched to a specific title or rank such as "assistant professor". Most data classified as "Other" constituted a wide variety of positions and titles and thus were not included in the data presented, as they could not be accurately grouped. In addition, because the data were sorted by factors such as faculty rank and contract duration, some groups of data were reduced to individual values that could be used to identify respondents. In these cases, the data were included in the mean total salary but not the salaries with or without extra compensation to ensure respondents' confidentiality.

\section{Statistical Analysis}

Total annual salary was defined as base salary plus any extra compensation. Extra compensation was defined as the approximate average yearly amount of total extra compensation such as summer contracts, secondary contracts or other types of compensation by your facility if not included in your base salary. Respondents were specifically asked not to consider retirement monies, medical, or insurance benefits as extra compensation. The mean total annual salary and standard deviation (SD) in U.S. dollars (USD) for all respondents was calculated. Salary data that fell outside 3 standard deviations were excluded from the study. These values were not representative of the data and had the potential for response error. For questions with specific answer choices, the respondent percentage (the number of respondents answering the question divided by the total number of respondents) and the response percentage (the number of responses to the question divided by the total 
number of responses) were calculated. Extra compensation and retirement benefits were calculated as the average of the total compensation or retirement benefits from those respondents stating that they received benefits and who provided an amount of benefit. Using Microsoft Excel, we calculated the mean, median, SD, standard error of the mean (SEM; calculated as $\mathrm{SD} / \mathrm{V}_{\mathrm{n}}$ ), 95\% confidence intervals (CIs; calculated as SEM * 1.96), and relative error of the mean (REM; calculated as $\mathrm{SEM} / \mathrm{mean}$ ) for each data set grouped by certification, degree, or position rank. Data sorted by specialty certification were compared using a Student t-test for two independent means with a significance level of $p<0.05$ and one-tailed hypothesis.

\section{RESULTS}

\section{Demographics of Respondents}

Three hundred fifteen laboratory science professionals responded to the survey. Respondents' self-identified specialties and certifications are shown in Table 2 and
Table 3, respectively. Aside from those whose specialties were molecular genetics, flow cytometry, or other categories, most respondents were evenly distributed among specialty areas (Table 2). In addition, 97.2\% of respondents reported having academic programs that were accredited by the NAACLS or were in serious applicant status. Just $2.8 \%$ of respondents reported having academic programs that were not accredited by the NAACLS (data not shown). Most respondents (about 93\%) had MLS or medical technologist (MT) certifications (Table 3). Of the professionals whose specialities were molecular biology, molecular genetics, flow cytometry, or histotechnology, 5\% had other certifications that may better fit their current positions (Table 3). Owing to low response rates, there were few salary data for professionals with credentials other than MLS/MT certifications, which made it difficult to draw conclusions about such groups. However, the survey did yield some data about professionals with molecular biology (MB) certifications.

\begin{tabular}{|c|c|c|c|}
\hline $\begin{array}{l}\% \text { is the total percent of those respond } \\
\% \text { is the percent of times a respondent } \\
\text { number of respondents with specialty }\end{array}$ & $\begin{array}{l}\text { to the survey ind } \\
\text { cted a specialty o } \\
\text { fications are indi }\end{array}$ & $\begin{array}{l}\text { ating they ide } \\
\text { er the total nu } \\
\text { ted by specia }\end{array}$ & $\begin{array}{l}\text { ed with a specialty. Respondent } \\
\text { r of specialties selected. The } \\
\text { lected.. }\end{array}$ \\
\hline Respondents by Self-Identified Specialty N=315 & Respondent \% & Response\% & Specialty Certifications \\
\hline Immunohematology & $31.11 \%$ & $13.78 \%$ & 2 DLM, 14SBB, 3SH, 2SM \\
\hline Hematology/Coagulation & $39.05 \%$ & $17.30 \%$ & $1 \mathrm{SBB}, 10 \mathrm{SH}$ \\
\hline Clinical Chemistry & $33.33 \%$ & $14.77 \%$ & 1SBB, 7SC, \\
\hline Microbiology & $36.83 \%$ & $16.32 \%$ & 1DLM, 1SC, 19SM \\
\hline Immunology & $24.44 \%$ & $10.83 \%$ & 1DLM, 2SBB, 2SC, 5SM, \\
\hline Urinalysis & $30.48 \%$ & $13.50 \%$ & 1SBB, 2SC, 1SM \\
\hline Molecular Genetics & $10.79 \%$ & $4.78 \%$ & 1SBB, 1SC, 3SM, 14MB \\
\hline Flow Cytometry & $1.27 \%$ & $0.56 \%$ & $1 \mathrm{SBB}$ \\
\hline Other & $18.41 \%$ & $8.16 \%$ & 2SBB, 2SC, 2SM \\
\hline
\end{tabular}

\begin{tabular}{|c|c|}
\hline Respondents By Self-Identified Certification N=310 & Respondent $\%$ \\
\hline Medical Laboratory Scientist or Medical Technologist (MLS/MT) & $90.65 \%$ \\
\hline Medical Technologist (AMT) & $2.26 \%$ \\
\hline Medical Laboratory Technician(ASCP) & $1.61 \%$ \\
\hline Medical Laboratory Technician(AMT) & $0.32 \%$ \\
\hline Other (MB, HT, Categorical, etc) & $5.16 \%$ \\
\hline
\end{tabular}




\section{EDUCATION}

\section{Highest Academic Degrees and Experience of Respondents}

Salary data were also sorted by respondents' highest academic degree and mean work experience (Table 4). Approximately $66 \%$ of the respondents had master's degrees, $23 \%$ had doctoral degrees, and $11 \%$ had bachelor's degrees. The mean clinical laboratory experience of respondents with bachelor's, master's, or doctoral degrees were 17.6, 16.4, and 11.4 years, respectively. The mean educator experience of respondents with bachelor's degrees, master's degrees, or doctoral degrees were 9.5, 15.4, and 18.2 years, respectively, indicating that respondents' experience as educators increased with academic degree level (Table 4). Interestingly, respondents with bachelor's degrees and those with master's degrees had mean research laboratory experience of only 0.2 and 0.4 years, respectively. In contrast, the mean research laboratory experience of MLS/MT educators with doctoral degrees was 3.8 years.

\begin{tabular}{|c|c|c|c|}
\hline Respondents by Self-Identified Degree N=282 & Bachelors Degree $\mathrm{N}=31$ & Masters Degree $\mathrm{N}=187$ & Doctoral Degree $N=64$ \\
\hline Highest Educational levels by respondents & $11.0 \%$ & $66.3 \%$ & $22.7 \%$ \\
\hline Average years of work in a clinical laboratory & 17.6 & 16.4 & 11.4 \\
\hline Average years of work as an educator & 9.5 & 15.4 & 18.2 \\
\hline Average years of work in a research laboratory & 0.2 & 0.4 & 3.8 \\
\hline
\end{tabular}

\section{Salary and Compensation Data}

The vast majority of survey respondents were MLS/MTcertified. Most respondents with bachelor's degrees did not receive additional compensation. In contrast, many respondents with master's or doctoral degrees received extra compensation for performing additional duties outside their contract periods.

\section{Salary and Benefits of MLS/MT-Certified Respondents by Highest Academic Degree}

The salary and benefits data of MLS/MT-certified respondents by highest academic degree are summarized in Table 5. The mean annual salary of MLS/MTcertified respondents with bachelor's degrees and 12month contracts was $\$ 61,823$ ( $n=17$; SEM, $\$ 2633$; 95\% CI, \$66,984-\$56,663; REM, 4.3\%). Respondents with master's degrees and doctoral degrees were paid differently based on contract duration. Most respondents had 9- or 12-month contracts. Some respondents reported receiving extra compensation in addition to their base salary. The base salaries reported as "with extra compensation" can be adjusted by the average extra compensation received to calculate total salary. The number of respondents with master's degrees and 9month contracts who received extra compensation was 5 times the number of respondents with master's degrees and 12-month contracts.
The mean salary of respondents with master's degrees and 9-month contracts who did not receive extra compensation was $\$ 58,147(\mathrm{n}=7)$. The mean salary of those who did receive additional compensation was $\$ 62,753$ ( $\mathrm{n}=34)$; however, the mean amount of extra compensation these respondents received was $\$ 10,375$, and thus these respondents' true mean salary was $\$ 73,138$. The mean annual salary of respondents with master's degrees and 9-month contracts was $\$ 70,570$ $(\mathrm{n}=41 ;$ SEM, $-\$ 3,000 ; 95 \%$ CI, \$64,693-\$76,447; REM, <5\%).

Among respondents with 12-month contracts, the number of respondents who received additional compensation was about half that of those who did not. The overall difference in salary between these two groups was $\$ 3,545$; those who received extra compensation had lower base pay but higher overall salaries. The mean annual salary of the 102 respondents with master's degrees and 12-month contracts was $\$ 73,569$ ( $\mathrm{n}=102$; SEM, \$1,496; 95\% CI, \$76,502-\$70,635; REM, $2.0 \%)$.

The mean salary of the respondents with doctoral degrees and 9-month contracts was $\$ 85,820 \quad(\mathrm{n}=20 ;$ SEM, $\$ 4,109 ; 95 \%$ CI, \$93,875-\$77,766; REM, 4.8\%). Among these 20 respondents, the mean salaries of the 17 respondents who did and the 3 respondents 
Table 5. MLS/MT average base salaries by degree earned. All averages were sorted by degree earned and contract length. Columns stating "no extra compensation" averages of respondents that indicated they were only paid a base salary. Columns stating "w/extra compensation" indicate the average base salary for the respondent's contract. Average extra compensation was determined as the average of dollar amount of those reporting extra compensation. Total compensation is determined by the average of all respondents based on annual earnings (base pay plus any additional compensation from their primary employer). Average retirement benefits are averages for those respondents reporting they received a retirement benefit sorted by degree. $\mathrm{N}$ equals the number of respondents in each category from left to right. All amounts are indicated in U.S. dollars.

\begin{tabular}{|c|c|c|c|c|c|c|c|c|}
\hline $\begin{array}{l}\text { MLS/MT Ave } \\
\text { Base salary levels } \\
\text { by Degree earned }\end{array}$ & $\begin{array}{c}\text { Employment } \\
\text { Terms }\end{array}$ & $\begin{array}{l}\text { Ave MT and } \\
\text { MLS } \\
\text { certification } \\
\text { (no extra } \\
\text { comp) }\end{array}$ & $\begin{array}{c}\text { Ave MT and } \\
\text { MLS } \\
\text { certification } \\
\text { (w/extra comp) }\end{array}$ & $\begin{array}{c}\text { Average } \\
\text { Extra Comp } \\
\text { (if earned) }\end{array}$ & $\begin{array}{l}\text { Total Annual } \\
\text { Salary (all } \\
\text { compensation) }\end{array}$ & $\begin{array}{c}\text { Standard } \\
\text { Error of } \\
\text { Mean }\end{array}$ & $\begin{array}{c}95 \% \\
\text { Confidence } \\
\text { intervals } \\
(+/-)\end{array}$ & $\begin{array}{l}\text { Relative } \\
\text { Error of } \\
\text { the } \\
\text { Mean }\end{array}$ \\
\hline $\begin{array}{l}\text { Bachelors Degree } \\
\mathrm{N}=22\end{array}$ & $\begin{array}{c}12 \mathrm{mo} \mathrm{N}=16 \\
\mathrm{~N}=17\end{array}$ & $\$ 61,575$ & & & $\$ 61,823$ & $\$ 2,633$ & $\$ 5,160$ & $4.3 \%$ \\
\hline \multirow[t]{3}{*}{$\begin{array}{l}\text { Masters Degree } \\
N=162\end{array}$} & $\begin{array}{c}9 \text { mo } N=7, \\
N=34, \\
N=34, N=41\end{array}$ & $\$ 58,147$ & $\$ 62,753$ & $\$ 10,375$ & $\$ 70,570$ & $\$ 2,999$ & $\$ 5,877$ & $4.2 \%$ \\
\hline & $\begin{array}{c}10 \text { mo } N=4, \\
N=10 \\
N=10, N=14\end{array}$ & $\$ 56,490$ & $\$ 68,075$ & $\$ 8,076$ & $\$ 70,533$ & $\$ 6,612$ & $\$ 12,959$ & $9.4 \%$ \\
\hline & $\begin{array}{c}11 \text { mo } \mathrm{N}=3, \\
\mathrm{~N}=2, \mathrm{~N}=2, \\
\mathrm{~N}=5\end{array}$ & $\$ 77,667$ & $\$ 61,500$ & $\$ 12,000$ & $\$ 76,000$ & $\$ 7,362$ & $\$ 14,430$ & $9.7 \%$ \\
\hline \multirow[t]{2}{*}{$\begin{array}{l}\text { Doctoral Degree } \\
N=52\end{array}$} & $\begin{array}{c}9 \text { mo } \mathrm{N}=3, \\
\mathrm{~N}=17, \\
\mathrm{~N}=17, \mathrm{~N}=20\end{array}$ & $\$ 91,000$ & $\$ 77,043$ & $\$ 7,864$ & $\$ 85,820$ & $\$ 4,109$ & $\$ 8,055$ & $4.8 \%$ \\
\hline & $\begin{array}{c}12 \text { mo } N=20, \\
N=6, N=6, \\
N=26\end{array}$ & $\$ 97,743$ & $\$ 100,431$ & $\$ 4,150$ & $\$ 99,321$ & $\$ 3,014$ & $\$ 5,908$ & $3.0 \%$ \\
\hline $\begin{array}{l}\text { Ave Retirement } \\
\text { Benefit (if } \\
\text { earned) Bachelors } \\
\mathrm{N}=14\end{array}$ & $\$ 4,018$ & & & & & & & \\
\hline $\begin{array}{l}\text { Ave Retirement } \\
\text { Benefit (If } \\
\text { earned) Masters } \\
\mathrm{N}=146\end{array}$ & $\$ 7,289$ & & & & & & & \\
\hline
\end{tabular}

who did not receive extra compensation were $\$ 77,043$ and $\$ 91,000$, respectively. The mean amount of extra compensation received was $\$ 7,864$.

The mean salary of the respondents with doctoral degrees and 12-month contracts was $\$ 99,321 \quad(\mathrm{n}=26 ;$ SEM, $\$ 3,014 ; 95 \% \mathrm{CI}, \$ 105,230-\$ 93,413$; REM, 3.0\%). Among these 26 respondents, the mean salaries of the 6 respondents who did and the 20 respondents who did not receive extra compensation were $\$ 97,743$ and $\$ 100,431$, respectively. The mean amount of extra compensation received was $\$ 4,150$.

The mean retirement benefits for respondents with bachelor's, master's, and doctoral degrees were $\$ 4,018$ $(n=14), \quad \$ 7,289 \quad(n=146), \quad$ and $\$ 8,045 \quad(n=47)$, respectively. In general, retirement benefits increased as salary increased.

\section{Salary and Benefits of MB-Certified Respondents by Highest Academic Degree}

The self reported salary data of MB-certified respond- 
Table 6. Average base salaries of molecular biology certified respondents by degree. All averages were sorted by degree earned and contract length. Columns stating "no extra compensation" averages of respondents that indicated they were only paid a base salary. Columns stating "w/extra compensation" indicate the average base salary for the respondent's contract. Average extra compensation was determined as the average of dollar amount of those reporting extra compensation. Total compensation is determined by the average of all respondents based on annual earnings (base pay plus any additional compensation from their primary employer). Average retirement benefits are averages for those respondents reporting they received a retirement benefit sorted by degree. $\mathrm{N}$ equals the number of respondents in each category from left to right. All amounts are indicated in U.S. dollars.

\begin{tabular}{|c|c|c|c|c|c|c|c|c|}
\hline $\begin{array}{l}\text { Molecular Biology } \\
\text { Certification (Ave Base } \\
\text { salary levels by Degree } \\
\text { earned) }\end{array}$ & $\begin{array}{l}\text { Employment } \\
\text { Terms } \\
\text { (Number of } \\
\text { Respondents) }\end{array}$ & $\begin{array}{l}\text { Ave Base } \\
\text { Salary (no } \\
\text { extra } \\
\text { comp) }\end{array}$ & $\begin{array}{l}\text { Ave Base } \\
\text { Salary } \\
\text { (w/extra } \\
\text { comp) }\end{array}$ & $\begin{array}{l}\text { Average } \\
\text { Extra } \\
\text { Comp (if } \\
\text { earned) }\end{array}$ & $\begin{array}{l}\text { Total Annual } \\
\text { Salary (all } \\
\text { compensation) }\end{array}$ & $\begin{array}{l}\text { Standard } \\
\text { Error of } \\
\text { Mean }\end{array}$ & $\begin{array}{l}95 \% \\
\text { Confidence } \\
\text { intervals } \\
(+/-) \\
\end{array}$ & $\begin{array}{l}\text { Relative } \\
\text { Error of } \\
\text { the Mean }\end{array}$ \\
\hline Masters Degree & $\begin{array}{c}12 \mathrm{mo}(\mathrm{N}=3 \\
\mathrm{N}=2, \mathrm{~N}=2 \\
\mathrm{~N}=5)\end{array}$ & $\$ 70,667$ & $\$ 107,000$ & $\$ 5,000$ & $\$ 87,200$ & $\$ 13,695$ & $\$ 26,841$ & $15.7 \%$ \\
\hline Doctoral Degree & $\begin{array}{c}9 \mathrm{mo}(\mathrm{N}=2, \\
\mathrm{N}=2) \\
12 \mathrm{mo}(\mathrm{N}=2, \\
\mathrm{N}=4, \mathrm{~N}=4 \\
\mathrm{~N}=6)\end{array}$ & $\$ 96,200$ & $\$ 102,781$ & $\$ 4,463$ & $\$ 96,200$ & $\$ 32,400$ & $\$ 63,504$ & $33.7 \%$ \\
\hline $\begin{array}{l}\text { Ave Retirement Benefit } \\
\text { (If earned) Masters } \mathrm{N}=4 \\
\text { Ave Retirement Benefit } \\
\text { (If earned) Doctoral } \\
\mathrm{N}=8\end{array}$ & $\$ 9,132$ & & & & & & & \\
\hline
\end{tabular}

ents by highest academic degree are summarized in Table 6. The mean salary of MB-certified respondents with master's degrees and 9-month contracts was $\$ 87,200$ $(\mathrm{n}=5$; SEM, \$13,695; 95\% CI, \$60,359-\$114,041; REM, 15.7\%). The mean salary of MB-certified respondents with doctoral degrees and 12-month contracts was $\$ 96,496$ ( $\mathrm{n}=6$; SEM, $\$ 10,267 ; 95 \% \mathrm{CI}$, $\$ 76,372-\$ 116,620 ;$ REM, $10.6 \%)$. The mean retirement benefits for respondents with master's and doctoral degrees were $\$ 9,132(n=4)$ and 8,039 ( $n=8)$, respectively. In general, retirement benefits increased as salary increased.

\section{Salary and Benefits of MLS/MT-Certified Respondents by Position Title}

The self-reported salary data of MLS/MT-certified respondents by position title are summarized in Table 7 . The average total salary compensation for respondents who indicated that they were managers/supervisors with a 12-month contract was $\$ 80,183(\mathrm{n}=14$; SEM, $\$ 6,069$; 95\% CI, \$68,233-92,132; REM, 7.6\%). Data for individuals who had 12-month contracts and received no additional compensation are also shown. The total salary compensation for full-time instructors/adjuncts/ lecturers varied by contract length and amount of extra compensation. The mean total annual salaries of fulltime instructors/adjuncts/lecturers with 9-, 10-, 11-, and 12 -month contracts were $\$ 62,936$ ( $n=22$; SEM, $\$ 2,999$;
95\% CI, \$57058-\$68813; REM, 4.8\%), \$60,386 ( $\mathrm{n}=9$; SEM, \$5,961; 95\% CI, \$48,703-\$7,068; REM, 9.9\%), $\$ 81,500(\mathrm{n}=2)$, and $\$ 64,240(\mathrm{n}=28$; SEM, $\$ 1,847 ; 95 \%$ CI, $\$ 60,619-\$ 67,8601$; REM, 2.9\%), respectively.

Among tenure-track faculty, total salary compensation for assistant professors varied by contract length and extra compensation. The mean total annual salaries of assistant professors with 9-, 10-, 11-, and 12-month contracts were $\$ 73,654(\mathrm{n}=7$; SEM, $\$ 8,581$; 95\% CI, \$56,835\$90,473; REM, 11.7\%), \$62,069 ( $\mathrm{n}=4$; SEM, $\$ 7,255$; 95\% CI, \$47848-\$76,289; REM, 11.7\% ), \$81,120 $(\mathrm{n}=2)$, and $\$ 73,867(\mathrm{n}=38 ;$ SEM, $\$ 1,793 ; 95 \% \mathrm{CI}$, $\$ 70,352-\$ 77,381$; REM, $2.4 \%$ ), respectively. The mean total annual salaries of associate professors with 9-, 10-, 11 -, and 12-month contracts were $\$ 78,201 \quad(\mathrm{n}=14$; SEM, $\$ 6,106,95 \%$ CI, \$66,234-\$90,169; REM, 7.8\%), $\$ 74,949 \quad(\mathrm{n}=4$; SEM, $\$ 19,958 ; 95 \%$ CI, $\$ 35,831$ $\$ 114,066$; REM, 26.6\%), $\$ 88,851 \quad(\mathrm{n}=2)$, and $\$ 94,104$ $(\mathrm{n}=23$; SEM, $\$ 3,544 ; 95 \%$ CI, $\$ 87,158$; REM, 3.8\%), respectively. The mean total annual salaries of full professors with 9-, 10-, and 12-month contracts were $\$ 87,329$ ( $\mathrm{n}=14$; SEM, $\$ 4,868 ; 95 \%$ CI, \$77,788$\$ 96,870$; REM, 5.6\%), $\$ 89,468(\mathrm{n}=2)$, and $\$ 82,935$ ( $\mathrm{n}=19$; SEM, $\$ 4,791$; 95\% CI, \$73,545-\$92,325; REM, $5.8 \%)$, respectively. 
Table 7. MLS/MT average base salary levels by self- reported position title. All averages were sorted by degree earned and contract length. Columns stating "no extra compensation" averages of respondents that indicated they were only paid a base salary. Columns stating "w/extra compensation" indicate the average base salary for the respondent's contract. Average extra compensation was determined as the average of dollar amount of those reporting extra compensation. Total compensation is determined by the average of all respondents based on annual earnings (base pay plus any additional compensation from their primary employer). Average retirement benefits are averages for those respondents reporting they received a retirement benefit sorted by degree. All amounts are indicated in U.S. dollars.

\begin{tabular}{|c|c|c|c|c|c|c|c|c|c|}
\hline & \multirow[b]{2}{*}{$\begin{array}{c}\text { Employment } \\
\text { Terms }\end{array}$} & \multicolumn{4}{|c|}{ Manager/Supervisor MT/MLS Certification } & \multicolumn{4}{|c|}{ Full-Time Instructor/Adjunct/Lecturer } \\
\hline & & $\begin{array}{c}\text { No extra } \\
\text { comp }\end{array}$ & $\begin{array}{c}\text { w/extra } \\
\text { comp }\end{array}$ & $\begin{array}{c}\text { Extra Comp } \\
\text { (if earned) }\end{array}$ & $\begin{array}{c}\text { Total } \\
\text { Annual } \\
\text { Salary }\end{array}$ & $\begin{array}{c}\text { No extra } \\
\text { comp }\end{array}$ & $\begin{array}{l}\text { w/extra } \\
\text { comp }\end{array}$ & $\begin{array}{c}\text { Extra } \\
\text { Comp (if } \\
\text { earned) } \\
\end{array}$ & $\begin{array}{c}\text { Total } \\
\text { Annual } \\
\text { Salary }\end{array}$ \\
\hline Average & $9 \mathrm{mo}$ & & & & & $\$ 64,004$ & $\$ 56,656$ & $\$ 5,781$ & $\$ 62,936$ \\
\hline $\begin{array}{l}\text { Median } \\
\text { Standard Error }\end{array}$ & & & & & & $\$ 60,000$ & $\$ 54,000$ & & $\$ 59,500$ \\
\hline $\begin{array}{l}\text { of Mean } \\
95 \%\end{array}$ & & & & & & $\$ 7,098$ & $\$ 3,075$ & & $\$ 2,999$ \\
\hline $\begin{array}{l}\text { Confidence } \\
\text { intervals }(+/-)\end{array}$ & & & & & & $\$ 13,912$ & $\$ 6,026$ & & $\$ 5,877$ \\
\hline $\begin{array}{l}\text { Relative } \\
\text { Standard Error }\end{array}$ & & & & & & $11.1 \%$ & $5.4 \%$ & & $4.8 \%$ \\
\hline Average & $10 \mathrm{mo}$ & & & & & $\$ 53,793$ & $\$ 60,520$ & $\$ 5,140$ & $\$ 60,386$ \\
\hline $\begin{array}{l}\text { Median } \\
\text { Standard Error }\end{array}$ & & & & & & $\$ 56,980$ & $\$ 52,000$ & & $\$ 58,500$ \\
\hline $\begin{array}{l}\text { of Mean } \\
95 \% \\
\text { Confidence }\end{array}$ & & & & & & $\$ 4,425$ & $\$ 9,135$ & & $\$ 5,961$ \\
\hline $\begin{array}{l}\text { intervals }(+/-) \\
\text { Relative }\end{array}$ & & & & & & $\$ 8,672$ & $\$ 17,905$ & & $\$ 11,683$ \\
\hline Standard Error & & & & & & $8.2 \%$ & $15.1 \%$ & & $9.9 \%$ \\
\hline Average & $11 \mathrm{mo}$ & & & & & & & & $\$ 81,500$ \\
\hline $\begin{array}{l}\text { Median } \\
\text { Standard Error }\end{array}$ & & & & & & & & & $\$ 81,500$ \\
\hline $\begin{array}{l}\text { of Mean } \\
95 \%\end{array}$ & & & & & & & & & $\$ 17,500$ \\
\hline $\begin{array}{l}\text { Confidence } \\
\text { intervals (+/-) } \\
\text { Relative }\end{array}$ & & & & & & & & & $\$ 34,300$ \\
\hline Standard Error & & & & & & & & & $21.5 \%$ \\
\hline Average & $12 \mathrm{mo}$ & $\$ 75,966$ & & & $\$ 80,183$ & $\$ 64,163$ & $\$ 60,085$ & $\$ 4,386$ & $\$ 64,240$ \\
\hline $\begin{array}{l}\text { Median } \\
\text { Standard Error }\end{array}$ & & $\$ 71,136$ & & & $\$ 75,318$ & $\$ 62,000$ & $\$ 60,696$ & & $\$ 62,448$ \\
\hline $\begin{array}{l}\text { of Mean } \\
95 \% \\
\text { Confidence }\end{array}$ & & $\$ 4,756$ & & & $\$ 6,096$ & $\$ 2,228$ & $\$ 3,910$ & & $\$ 1,847$ \\
\hline $\begin{array}{l}\text { intervals (+/-) } \\
\text { Relative }\end{array}$ & & $\$ 9,321$ & & & $\$ 11,949$ & $\$ 4,368$ & $\$ 7,663$ & & $\$ 3,621$ \\
\hline Standard Error & & $6.3 \%$ & & & $7.6 \%$ & $3.5 \%$ & $6.5 \%$ & & $2.9 \%$ \\
\hline
\end{tabular}

Salary of MLS/MT-Certified Respondents by Community College Sorted By Position Title

The self-reported salary data of MLS/MT-certified respondents by position title sorted by community college as a location of employment are summarized in Table 8. The average total salary compensation for respondents who indicated that they were full-time instructors/adjuncts/lecturers with a 9-, 10-, and 12month contracts were $\$ 61,721 \quad(\mathrm{n}=16$; SEM, $\$ 3,097$; 95\% CI, \$55,650-67,792; REM, 5.0\%), \$54,359 ( $\mathrm{n}=7$; SEM, \$3,408; CI, \$47,680-61,038; REM 6.3\%), and $\$ 66,490 \quad(\mathrm{n}=10$; SEM, $\$ 3,364$; CI, \$59,896-73,084; REM 5.1\%), respectively. Total salary for individuals at community colleges who had 10- and 12- month assist- 


\begin{tabular}{|c|c|c|c|c|c|c|c|c|c|}
\hline & \multirow[b]{2}{*}{$\begin{array}{l}\text { Employment } \\
\text { Terms }\end{array}$} & \multicolumn{4}{|c|}{ Assistant Professor } & \multicolumn{4}{|c|}{ Associate Professor } \\
\hline & & $\begin{array}{l}\text { No extra } \\
\text { comp }\end{array}$ & $\begin{array}{l}\text { w/extra } \\
\text { comp }\end{array}$ & $\begin{array}{c}\text { Extra Comp } \\
\text { (if earned) }\end{array}$ & $\begin{array}{c}\text { Total } \\
\text { Annual } \\
\text { Salary } \\
\end{array}$ & $\begin{array}{c}\text { No extra } \\
\text { comp }\end{array}$ & $\begin{array}{l}\text { w/extra } \\
\text { comp }\end{array}$ & $\begin{array}{c}\text { Extra } \\
\text { Comp (if } \\
\text { earned) }\end{array}$ & $\begin{array}{c}\text { Total } \\
\text { Annual } \\
\text { Salary } \\
\end{array}$ \\
\hline Average & $9 \mathrm{mo}$ & $\$ 66,500$ & $\$ 65,222$ & $\$ 11,293$ & $\$ 73,654$ & & $\$ 68,932$ & $\$ 9,269$ & $\$ 78,201$ \\
\hline $\begin{array}{l}\text { Median } \\
\text { Standard Error }\end{array}$ & & $\$ 66,500$ & $\$ 68,000$ & & $\$ 76,000$ & & $\$ 68,233$ & & $\$ 74,483$ \\
\hline $\begin{array}{l}\text { of Mean } \\
95 \%\end{array}$ & & $\$ 9,500$ & $\$ 8,306$ & & $\$ 8,581$ & & $\$ 4,903$ & & $\$ 6,106$ \\
\hline $\begin{array}{l}\text { Confidence } \\
\text { intervals }(+/-) \\
\text { Relative }\end{array}$ & & $\$ 18,620$ & $\$ 16,280$ & & $\$ 16,819$ & & $\$ 9,610$ & & $\$ 11,968$ \\
\hline Standard Error & & $14.3 \%$ & $12.7 \%$ & & $11.7 \%$ & & $7.1 \%$ & & $7.8 \%$ \\
\hline Average & $10 \mathrm{mo}$ & & $\$ 56,955$ & $\$ 5,114$ & $\$ 62,069$ & $\$ 55,333$ & & & $\$ 74,949$ \\
\hline $\begin{array}{l}\text { Median } \\
\text { Standard Error }\end{array}$ & & & $\$ 51,028$ & & $\$ 56,245$ & $\$ 56,000$ & & & $\$ 60,000$ \\
\hline $\begin{array}{l}\text { of Mean } \\
95 \%\end{array}$ & & & $\$ 7,551$ & & $\$ 7,255$ & $\$ 5,207$ & & & $\$ 19,958$ \\
\hline $\begin{array}{l}\text { Confidence } \\
\text { intervals (+/-) } \\
\text { Relative }\end{array}$ & & & $\$ 14,800$ & & $\$ 14,220$ & $\$ 10,205$ & & & $\$ 39,117$ \\
\hline Standard Error & & & $13.3 \%$ & & $11.7 \%$ & $9.4 \%$ & & & $26.6 \%$ \\
\hline Average & $11 \mathrm{mo}$ & $\$ 81,120$ & & & $\$ 81,120$ & & & & $\$ 88,851$ \\
\hline $\begin{array}{l}\text { Median } \\
\text { Standard Error }\end{array}$ & & $\$ 81,120$ & & & $\$ 81,120$ & & & & $\$ 88,851$ \\
\hline $\begin{array}{l}\text { of Mean } \\
95 \% \\
\text { Confidence }\end{array}$ & & $\$ 4,120$ & & & $\$ 4,120$ & & & & $\$ 7,836$ \\
\hline $\begin{array}{l}\text { intervals }(+/-) \\
\text { Relative }\end{array}$ & & $\$ 8,075$ & & & $\$ 8,075$ & & & & $\$ 15,359$ \\
\hline Standard Error & & $5.1 \%$ & & & $5.1 \%$ & & & & $8.8 \%$ \\
\hline Average & $12 \mathrm{mo}$ & $\$ 72,852$ & $\$ 69,103$ & $\$ 6,504$ & $\$ 73,867$ & $\$ 92,063$ & $\$ 94,000$ & $\$ 7,450$ & $\$ 94,104$ \\
\hline $\begin{array}{l}\text { Median } \\
\text { Standard Error }\end{array}$ & & $\$ 70,150$ & $\$ 70,500$ & & $\$ 72,500$ & $\$ 87,000$ & $\$ 86,000$ & & $\$ 89,600$ \\
\hline $\begin{array}{l}\text { of Mean } \\
95 \%\end{array}$ & & $\$ 2,037$ & $\$ 3,403$ & & $\$ 1,793$ & $\$ 3,683$ & $\$ 12,276$ & & $\$ 3,544$ \\
\hline $\begin{array}{l}\text { Confidence } \\
\text { intervals }(+/-) \\
\text { Relative }\end{array}$ & & $\$ 3,992$ & $\$ 6,671$ & & $\$ 3,515$ & $\$ 7,218$ & $\$ 24,061$ & & $\$ 6,946$ \\
\hline Standard Error & & $2.8 \%$ & $4.9 \%$ & & $2.4 \%$ & $4.0 \%$ & $13.1 \%$ & & $3.8 \%$ \\
\hline
\end{tabular}

ant professor contracts were $\$ 54,992 \quad(\mathrm{n}=3$; SEM, $\$ 2,259$; CI, $\$ 50,565-59,419$; REM 4.1\%) and $\$ 70,342$ ( $\mathrm{n}=6$; SEM, \$4,718; CI, \$61,092-79,592; REM 6.7\%). Associate professors at community colleges responding to the survey had 9 mo contracts with an average salary of \$55,948 ( $\mathrm{n}=4$; SEM, \$5,035; CI, \$46,079-65,817; REM $9.0 \%)$. The total salary compensation for full professors varied by contract length and amount of extra compensation. The mean total annual salaries of full professors with 9- and 12-month contracts were $\$ 75,525$ $(\mathrm{n}=8$; SEM, $\$ 4,510$; 95\% CI, \$66,875-\$84,365; REM,
$6.0 \%)$ and $\$ 78,205(\mathrm{n}=13$; SEM, $\$ 4,125 ; 95 \% \mathrm{CI}$, \$70,119-\$86,291; REM, 5.3\%).

\section{Salary of MLS/MT-Certified Respondents by University} Sorted By Position Title

The self-reported salary data of MLS/MT-certified respondents by position title sorted by universities (excludes university hospitals) as a location of employment are summarized in Table 9. The average total salary compensation for respondents who indicated that they were full-time instructors/adjuncts/lecturers 
EDUCATION

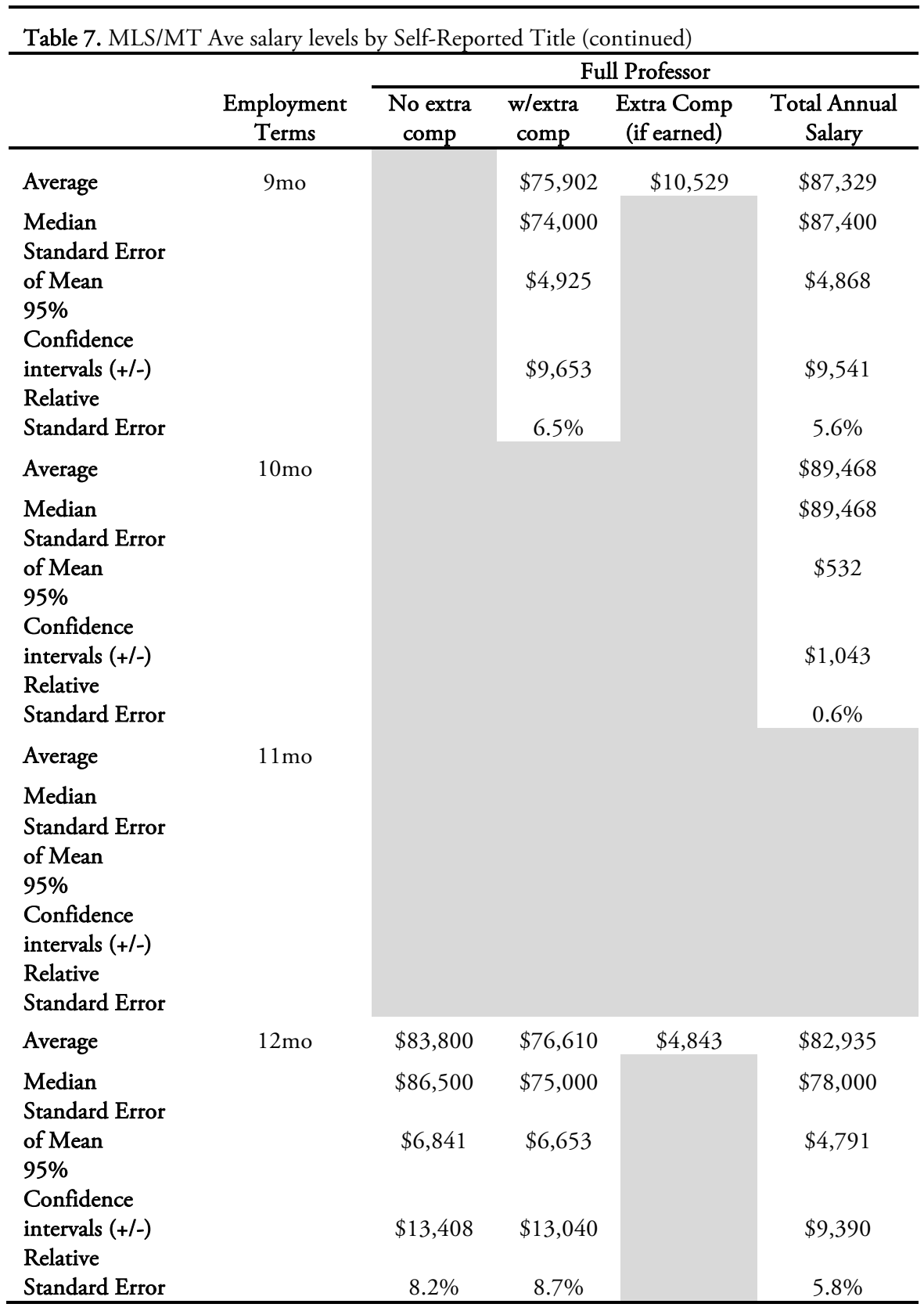

with a 9- and 12-month contracts were $\$ 67,732$ ( $\mathrm{n}=5$; SEM, \$8,992; 95\% CI, \$50,108-85,356; REM, 13.3\%, $\$ 64,675(\mathrm{n}=12$; SEM, \$3,173; CI, \$58,456-70,894; REM 4.9\%), respectively. Total salary for individuals at universities who had 9- and 12- month assistant professor contracts were $\$ 76,550 \quad(\mathrm{n}=6$; SEM, \$9,558; CI, $\$ 57,817-95,283$; REM 12.5\%) and $\$ 75,361 \quad(\mathrm{n}=28$; SEM, \$2,167; CI, \$71,115-79,609; REM 2.9\%). Associate professors at universities responding to the survey had $9 \mathrm{mo}$ contracts with an average salary of $\$ 87,102(\mathrm{n}=10 ;$ SEM, \$6,419; CI, \$74,521-99,683; REM $7.4 \%$ ) compared with those of 12 mo contracts with an average salary of $\$ 89,891$ ( $\mathrm{n}=17$; SEM, $\$ 3,431$; CI, \$83,167-96,615; REM 3.8\%). The total salary compensation for full professors varied by contract length and amount of extra compensation. The mean total annual salaries of full professors at universities with 9- and 12-month contracts were $\$ 103,068$ ( $\mathrm{n}=6$; SEM, \$4,369; 95\% CI, \$94,504-\$111,632; REM, 4.2\%) and $\$ 91,420 \quad(\mathrm{n}=5$; SEM, $\$ 14,458$; 95\% CI, \$63,083\$119,757; REM, 15.8\%). 


\section{EDUCATION}

\section{Salary of MLS/MT-Certified Respondents by Location of Employment}

Respondents' self-reported salary data by location of employment are summarized in Table 10 . The mean and median salaries of respondents employed at community colleges were $\$ 68,387$ and $\$ 65,100$, respectively $(n=86$; SEM, \$1,730; 95\% CI, \$64,995-\$71,778; REM, 2.5\%). Salaries were slightly lower for respondents employed at hospitals, who had mean and median salaries of $\$ 72,737$ and $\$ 70,818$, respectively $(\mathrm{n}=26$; SEM, $\$ 3,686 ; 95 \% \mathrm{CI}$, $\$ 65,511-\$ 79,963$; REM, 5.1\%). The mean and median salaries of respondents employed at universities $(\$ 78,698$ and $\$ 77,700$, respectively; $\mathrm{n}=113$; SEM, $\$ 1,862 ; 95 \%$ CI, \$75,047-\$82,438; REM, 2.4\%) were higher than those of respondents employed at community colleges or hospitals. Respondents employed at university hospitals had the highest mean and median salaries $(\$ 92,232$ and $\$ 98,000$, respectively; $\mathrm{n}=11$; SEM, 8,148; 95\% CI, $\$ 76,260-\$ 108,203$; REM 8.8\%). The REM was less than $10 \%$ for each group and lowest for the group whose employment location yielded the highest number of respondents.

\section{Salary of MLS/MT-Certified Professionals by Specialist Certification}

Faculty salaries were assessed by specialty certification and summarized in Table 11. The average salary of SSBcertified respondents was $\$ 70,832(n=12$; SEM, 4,859; 95\% CI, \$61,309-\$80,355; REM 6.9\%). Specialist in Chemistry (SC)-certified respondents had an average salary of $\$ 73,756$ ( $n=6$; SEM, $\$ 3,637$; 95\% CI, \$66,629\$99,930; REM, 4.9\%). Respondents with Specialist in Hematology $(\mathrm{SH})$ certifications had an average salary of $\$ 92,916 \quad(\mathrm{n}=6 ;$ SEM, $\$ 9,529 ; 95 \%$ CI, \$74,238$\$ 111,593$; REM, 10.3\%). The average salary for Specialist in Microbiology (SM)-certified respondents was $\$ 87,345$ ( $\mathrm{n}=15$; SEM, $\$ 5,318$; 95\% CI, $\$ 76,922-$ $\$ 97,768$; REM, 6.1\%). Because the number of respondents who reported having a specialty certification was lower than the total number of people who took the survey, the interpretation of the salary data is limited when comparing them across specialty certifications. The differences in mean salary between Specialist in Blood Banking (SBB)- and SC-certified respondents, between $\mathrm{SC}$ - and SM-certified respondents, and between $\mathrm{SH}$ - and SM-certified respondents were not significant $(p=0.35$, 0.07 , and 0.30 , respectively). However, there were significant differences in salary between SBB- and SHcertified respondents $(p=0.02)$, between SBB- and SM- certified respondents $(p=0.02)$, and between $\mathrm{SH}$ - and SM-certified respondents $(p=0.04)$. These significant differences are likely linked to position-specific requirements, which were not assessed in this study.

\section{Faculty Unionization by MLS/MT-Certified Professionals}

Of the survey respondents, $22.8 \%$ reported that their institution had a union (data not shown). Of the respondents who reported a union, $60 \%$ indicated that they were union members. Overall, $13.4 \%$ of respondents indicated that they were union members (data not shown). The salaries of individuals with union membership and without union membership did not differ significantly $(\mathrm{p}=0.09)$.

\section{DISCUSSION}

In conducting our salary survey study, we sought to make salary data available to decision-makers and professionals in the medical laboratory science field. This study examined the demographics and salary information of respondents to our survey.

In the current literature, there is very little information about faculty salaries in medical laboratory science. In addition, the data that are available are proprietary in nature and require a payment or subscription to obtain. The College and University Professional Association for Human Resources is one such organization that compiles salary data using 4 or 6 digit CIP codes. CIP code 51.XXXX is used for health professions and related clinical sciences. Human resources departments reporting salary data are allowed to submit information using four-digit (51.10 for Clinical/Medical Laboratory Science/Research and Allied Professions [previously Clinical/Medical Laboratory Science and Allied Professions]) or six-digit (51.1006, Clinical Laboratory Science/Medical Technology/Technologist) codes. Data reported as four-digit codes are placed in the same salary category. However, several professionals listed in this area have distinct scopes of practice (Table 1). We do not believe that salary data from workers with varying scopes of practice, varying requirements for terminal degrees, and differing requirements for certification are specific enough to accurately reflect the salary of medical laboratory professionals.

The people who responded to our survey were MLSs with a variety of specialties. Each of the four major 
Table 8. MLS/MT average base salary levels by self- reported community college position titles. All averages were sorted by degree earned and contract length. Columns stating "no extra compensation" averages of respondents that indicated they were only paid a base salary. Columns stating "w/extra compensation" indicate the average base salary for the respondent's contract. Average extra compensation was determined as the average of dollar amount of those reporting extra compensation. Total compensation is determined by the average of all respondents based on annual earnings (base pay plus any additional compensation from their primary employer). Average retirement benefits are averages for those respondents reporting they received a retirement benefit sorted by degree. All amounts are indicated in U.S. dollars.

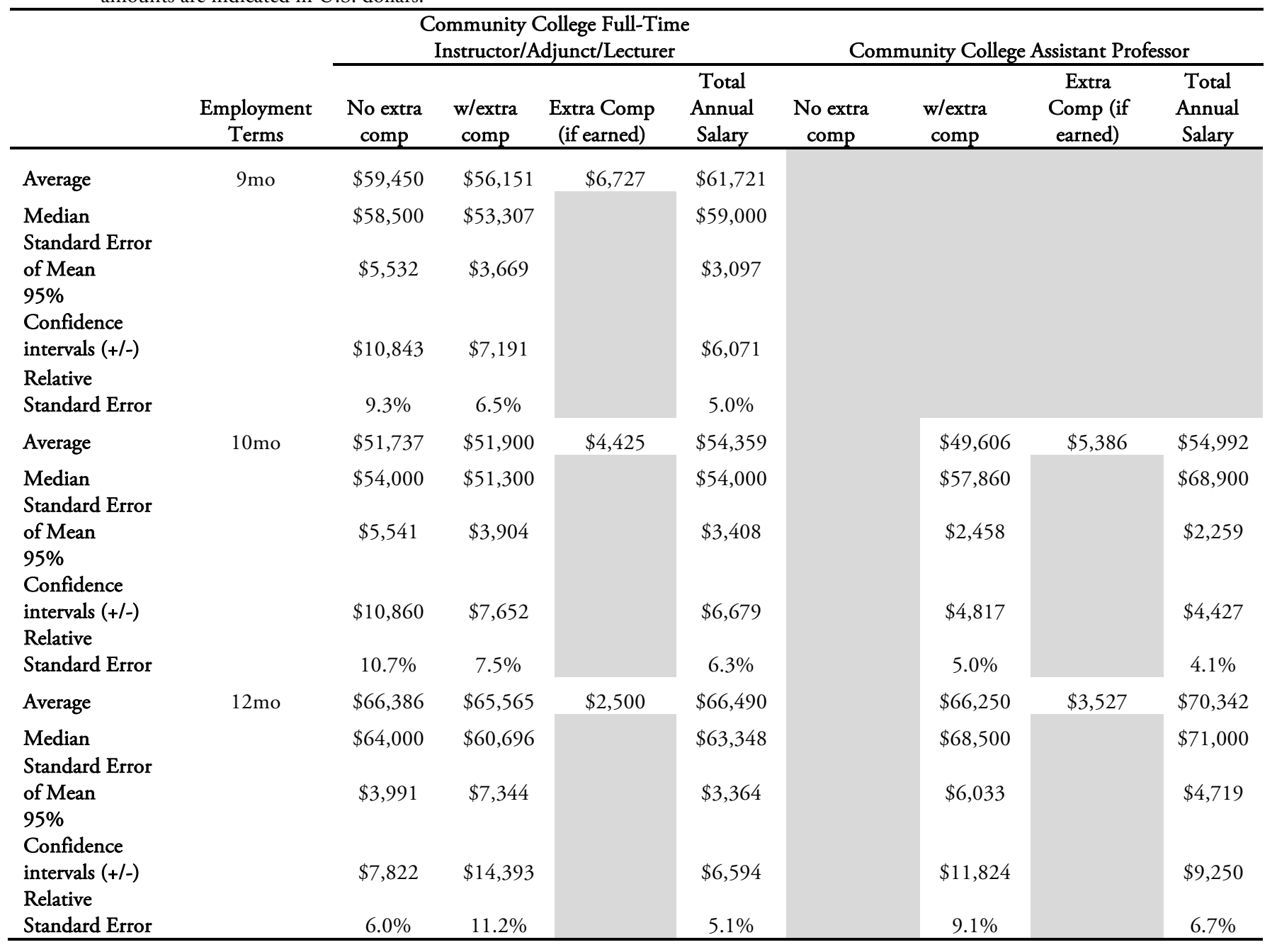

categories of medical laboratory scienceimmunohematology, hematology/coagulation, clinical chemistry, and microbiology-were represented in roughly equal measure $(30 \%-40 \%)$ and provide a fairly even population for analysis based on respondent percentage. It should be noted that many respondents selected more than one category of specialty, thus numbers do not add up to $100 \%$. Most faculty members who responded reported having the MLS or MT certification required to be an educator in accredited programs (Table 3). Overall, we believe that this demographic accurately represents the field of medical laboratory science, particularly for respondents with MLS or MT certification.
In addition to assessing certification, we examined the degree status of respondents. The generally accepted practice for examining degrees is to examine them by the highest degree completed. Table 4 shows the respondents by degree completed in conjunction with their average work experience in clinical laboratories, as educators, and in research laboratories. Of the respondents, $66.7 \% \mathrm{had}$ master's degrees as their highest degrees. This was not surprising, as anecdotal evidence through personal communication, meeting announcements, and listserv communications has indicated that educator vacancies are commonly filled by professionals with MLS certifications whose highest 
Table 8. MLS/MT Community College Ave salary levels by Self-Reported Title (continued)

\begin{tabular}{|c|c|c|c|c|c|c|c|c|c|}
\hline & \multirow[b]{2}{*}{$\begin{array}{c}\text { Employment } \\
\text { Terms }\end{array}$} & \multicolumn{4}{|c|}{ Community College Associate Professor } & \multicolumn{4}{|c|}{ Community College Full Professor } \\
\hline & & $\begin{array}{l}\text { No extra } \\
\text { comp }\end{array}$ & $\begin{array}{c}\text { w/extra } \\
\text { comp }\end{array}$ & $\begin{array}{c}\text { Extra Comp } \\
\text { (if earned) }\end{array}$ & $\begin{array}{c}\text { Total } \\
\text { Annual } \\
\text { Salary } \\
\end{array}$ & $\begin{array}{c}\text { No extra } \\
\text { comp }\end{array}$ & $\begin{array}{c}\text { w/extra } \\
\text { comp }\end{array}$ & $\begin{array}{c}\text { Extra } \\
\text { Comp (if } \\
\text { earned) } \\
\end{array}$ & $\begin{array}{c}\text { Total } \\
\text { Annual } \\
\text { Salary }\end{array}$ \\
\hline Average & $9 \mathrm{mo}$ & & $\$ 50,323$ & $\$ 5,625$ & $\$ 55,948$ & & $\$ 65,625$ & $\$ 9,900$ & $\$ 75,525$ \\
\hline $\begin{array}{l}\text { Median } \\
\text { Standard Error }\end{array}$ & & & $\$ 46,646$ & & $\$ 55,646$ & & $\$ 61,500$ & & $\$ 78,000$ \\
\hline $\begin{array}{l}\text { of Mean } \\
95 \%\end{array}$ & & & $\$ 4,270$ & & $\$ 5,035$ & & $\$ 3,991$ & & $\$ 4,510$ \\
\hline $\begin{array}{l}\text { Confidence } \\
\text { intervals (+/-) } \\
\text { Relative }\end{array}$ & & & $\$ 8,368$ & & $\$ 9,869$ & & $\$ 7,822$ & & $\$ 8,840$ \\
\hline Standard Error & & & $8.5 \%$ & & $9.0 \%$ & & $6.1 \%$ & & $6.0 \%$ \\
\hline Average & $10 \mathrm{mo}$ & & & & & & & & \\
\hline $\begin{array}{l}\text { Median } \\
\text { Standard Error } \\
\text { of Mean } \\
95 \% \\
\text { Confidence } \\
\text { intervals (+/-) } \\
\text { Relative } \\
\text { Standard Error }\end{array}$ & & & & & & & & & \\
\hline Average & $12 \mathrm{mo}$ & & & & & $\$ 79,500$ & $\$ 71,879$ & $\$ 4,817$ & $\$ 78,205$ \\
\hline Median & & & & & & $\$ 74,500$ & $\$ 68,500$ & & $\$ 74,500$ \\
\hline $\begin{array}{l}\text { Standard Error } \\
\text { of Mean }\end{array}$ & & & & & & $\$ 6,783$ & $\$ 5,534$ & & $\$ 4,125$ \\
\hline $\begin{array}{l}95 \% \\
\text { Confidence }\end{array}$ & & & & & & & & & \\
\hline $\begin{array}{l}\text { intervals (+/-) } \\
\text { Relative }\end{array}$ & & & & & & $\$ 13,295$ & $\$ 10,847$ & & $\$ 8,086$ \\
\hline Standard Error & & & & & & $8.5 \%$ & $7.7 \%$ & & $5.3 \%$ \\
\hline
\end{tabular}

academic degrees are master's degrees. Interestingly, as degree level increased, work experience in clinical labs declined, whereas experience in education and research labs increased. In addition, those with master's degrees had very little research experience (Table 4). Further research is necessary to determine the cause of the lack of research experience among respondents with master's degrees. One possibility is that some respondents may have obtained degrees in education rather than in life science fields, and such respondents may not conduct research in research laboratories.

Respondents with doctoral degrees spent 3.8 years in research laboratories on average. Most classically trained individuals with basic science doctoral degrees must work in a research laboratories for 3-6 years to obtain their degrees. In addition, those pursuing doctoral degrees may spend time outside the clinical laboratory to gain experience in basic science research during their degree programs, which require 5-6 years on average to complete. In addition, most such individuals also complete at least 3 years of post-doctoral work, which could also account for the 5 -year decrease in clinical laboratory experience. In the present study, the average research laboratory experience of the respondents who indicated they had experience was 8 years (median, 6 years; $n=30$; data not shown). However, roughly half $(n=34)$ of the respondents with educator experience had no research laboratory experience; some respondents may have obtained doctoral degrees in areas such as education, which offer more programs through distance education formats but do not have laboratory research requirements. Some of these respondents also may have been doing clinical research, which they may have reported as clinical laboratory experience but not basic science research. These findings may also indicate that educators tend to pursue higher academic degrees over time. Doing so may be tied to a desire for increased pay, 
Table 9. MLS/MT average base salary levels by self- reported university position titles. All averages were sorted by degree earned and contract length. Columns stating "no extra compensation" averages of respondents that indicated they were only paid a base salary. Columns stating "w/extra compensation" indicate the average base salary for the respondent's contract. Average extra compensation was determined as the average of dollar amount of those reporting extra compensation. Total compensation is determined by the average of all respondents based on annual earnings (base pay plus any additional compensation from their primary employer). Average retirement benefits are averages for those respondents reporting they received a retirement benefit sorted by degree. All amounts are indicated in U.S. dollars.

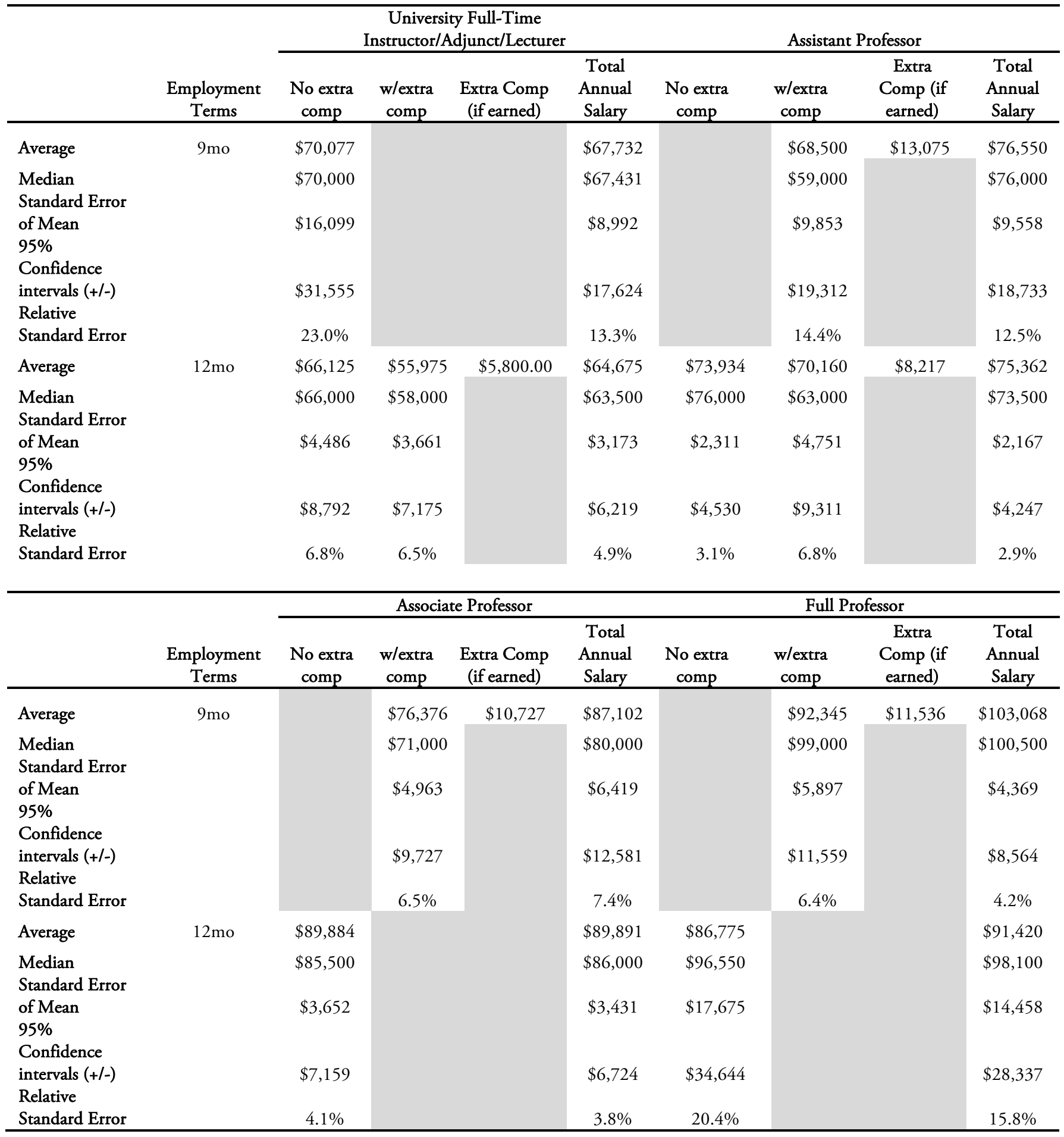




\section{EDUCATION}

a desire to be a more effective educator, and/or a need to meet requirements for academic positions.

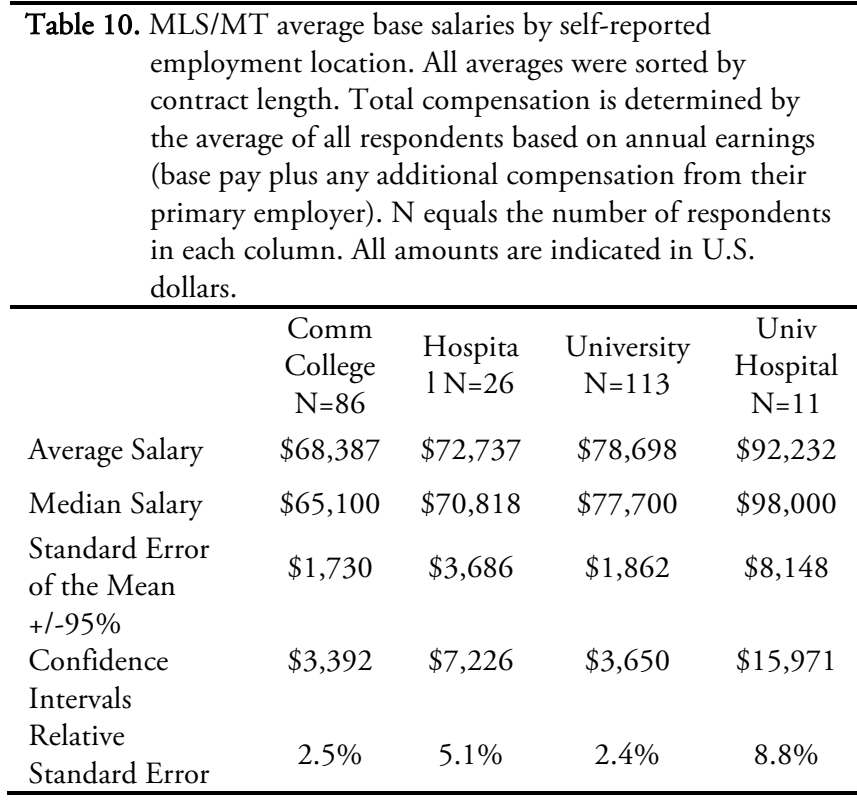

Table 11. MLS/MT average base salaries by self- reported specialty certification. All averages were sorted by contract length. Total compensation is determined by the average of all respondents based on annual earnings (base pay plus any additional compensation from their primary employer). $\mathrm{N}$ equals the number of respondents in each column. All amounts are indicated in U.S. dollars.

\begin{tabular}{lcccc}
\hline & SBB & SC & SH & SM \\
& $(\mathrm{N}=12)$ & $(\mathrm{N}=6)$ & $(\mathrm{N}=6)$ & $(\mathrm{N}=15)$ \\
Average Salary & $\$ 70,832$ & $\$ 73,756$ & $\$ 92,916$ & $\$ 87,345$ \\
$\begin{array}{l}\text { Median Salary } \\
\text { Standard }\end{array}$ & $\$ 74,500$ & $\$ 73,000$ & $\$ 88,500$ & $\$ 82,676$ \\
$\begin{array}{l}\text { Error of the } \\
\text { mean }\end{array}$ & $\$ 4,859$ & $\$ 3,637$ & $\$ 9,529$ & $\$ 5,318$ \\
$\begin{array}{l}95 \% \\
\text { Confidence }\end{array}$ & $\$ 9,523$ & $\$ 7,128$ & $\$ 18,677$ & $\$ 10,423$ \\
$\begin{array}{l}\text { Intervals }+/- \\
\text { Relative } \\
\text { Standard }\end{array}$ & & & & \\
Error & $6.9 \%$ & $4.9 \%$ & $10.3 \%$ & $6.1 \%$ \\
\hline
\end{tabular}

MLS/MT faculty in academic institutions have a variety of contract structures (Table 5). In most cases, those with longer contracts receive more total compensation than those with shorter contracts do, but items such as vacation time, flexible schedules, and related factors prevent further interpretation of total salary data.

Therefore, directly ascertaining respondents' motives or purposes for selecting the type of contract or its total compensation from salary data alone is impossible. It is more useful to perform additional studies to document salary trends over time. We believe salary data should be available to employers and employees alike, as many human resource departments and clinical professionals need such data to inform decisions about the many types of contracts they offer or receive. In addition, many faculty members-especially those with contract durations shorter than 12 months-received compensation outside their contracts. This is consistent with anecdotal evidence that suggests that many faculty members teach or perform additional work for their institutions outside their contracts. Some individuals with shorter contract durations may prefer to have more time off and/or more flexibility in their schedules; work overtime; or perform additional duties outside the scope of their contracts. Most respondents who have full-year contracts receive a base salary as their sole compensation, but a substantial number of respondents with 12-month contracts received additional compensation, which may have been given for working overtime or performing other job duties beyond the scope of their primary contract.

On average, MLS/MT-certified respondents with bachelor's degrees received 12-month contracts worth $\$ 61,823$, and this may serve as a baseline for judging the impact that advanced degrees such as master's and doctoral degrees have on salary. Among respondents with master's degrees, the salaries of those who had different contract durations appear to have CIs that overlap with those of the salaries of respondents who had contracts with longer durations and received slightly more compensation. The data seem to indicate that respondents with master's degrees and longer contracts are working at a substantial discount. Further interpretation of these data is difficult, as the numbers of additional hours respondents with shorter contracts worked for extra compensation and the numbers of hours respondents with longer contracts worked could be the same or vastly different, making it difficult to quantify their salary compensation per hours worked. If all respondents had equivalent work times, respondents with longer contracts would receive less money per month. Variations in respondents' paid time off, required work hours per week, required hours for additional compensation, and similar factors are difficult to control for and compare. Thus, the salary data are presented in their entirety where possible to provide a 


\section{EDUCATION}

reference for as many professionals as possible. Based on the data collected, professionals who have doctoral degrees and 12-month contracts receive higher salaries than professionals who have doctoral degrees and 9month contracts do. This is logical, as those with 12month contracts are likely required to work more hours during a calendar year. Similarly, professionals with master's degrees and 12-month contracts appear to be working the extra months at a discounted rate. This is a bit simplistic, as perhaps a larger base salary over more months benefits both the employee and employer, thereby warranting such a discount. Thus, employers and employees should use these data cautiously, as each situation is unique. Based on the salary data of respondents with 12 -month contracts, higher salaries tended to accompany higher academic degrees. In fact, the salaries of respondents with master's degrees were on average $\$ 11,745$ higher than those of respondents with bachelor's degree. The difference in salary between respondents with master's degrees and those with doctoral degrees was a striking $\$ 25,753$. In addition, our data show that higher retirement benefit amounts also tended to accompany higher academic degrees. Most retirement benefits are linked to salary on a percentage basis, so it is not surprising those who receive more salary would also receive more retirement benefits.

There were enough MB-certified respondents to examine their salaries (Table 6), but the small number of respondents limits the robustness of the salary data. Nevertheless, these data may be valuable, particularly if few or no salary data for these professionals are currently available. In future salary survey studies, the number of respondents with $\mathrm{MB}$ certifications may be larger. Despite the lower confidence in these data, they have some utility as lower and upper salary limits. The CIs of the salaries of the respondents with master's degrees and those of the salaries of respondents with doctoral degrees overlap substantially. A closer examination of the lower end of these limits indicates an approximately $\$ 16,000$ difference in salary between these groups, but there are too few respondents to draw additional conclusions. Still, these data may provide some basic parameters for likely salary ranges in future studies.

Since salaries for individuals change over time, we believed it was important to examine faculty rank and its effect on salary. One challenge of salary studies in the clinical laboratory science field is the various structures of educational programs. There are a variety of programs in hospital, community college, and university settings. Each type of program uses a variety of titles for its educators including special titles for clinical coordinators, program directors, and those with other specialized roles. Among respondents with 12-month contracts, full-time instructors/adjuncts/lecturers had mean annual salary of $\$ 64,240$, whereas full-time assistant professors had a mean salary of $\$ 73,867$. Interestingly, the mean salary of associate professors $(\$ 94,104)$ was higher than that of full professors $(\$ 82,935)$. This is because most respondents in the full professor category were from community colleges. When this is examined further, full professors at universities had an average total salary of $\$ 103,068$ (median, $\$ 100,500$ ) for 9 mo contracts and $\$ 91,420$ (median, $\$ 98,100$ ) for 12 mo contracts (Table 9), while those at community colleges had an average total salary of $\$ 75,525$ (median, $\$ 78,000$ ) for $9 \mathrm{mo}$ contracts and $\$ 78,205$ (median 74,500 ) for $12 \mathrm{mo}$ contracts (Table 8). With these adjustments, the mean salary ranges from $\$ 64,675$ for lecturers to $\$ 103,068$ for full professors at universities while salary ranges from $\$ 54,359$ for lecturers to $\$ 78,205$ for full professors at community colleges. The mean salary of managers/supervisors was $\$ 80,182$ (Table 7), which is close to the midpoint of faculty ranks at universities shown above.

Our study indicates that the faculty salaries at universities and university hospitals are higher than those at community colleges and non-university hospitals (Table 10). Several factors may account for this. For example, many community colleges likely teach MLT students at the associate level but may not have many doctoral-level faculty members teaching in those settings. These salary data seem to be in agreement with the standard that salaries for faculty members increase with their qualifications and the terminal degrees of the programs in which they teach.

We also examined salary by specialty certification (Table 11). We found significant salary differences between some respondents grouped by specialty certification, but these differences are likely linked to job-specific requirements. In addition, position descriptions and job duties are likely more important factors but were not assessed in this study. Nevertheless, providing this information is important, as no studies have assessed the effect of specialty certification on faculty salaries in the 
clinical laboratory science field.

\section{CONCLUSION}

This study was the first to examine the faculty salaries of clinical laboratory scientists. The salary information is extremely valuable to employers and employees alike. The data collected using our survey provides new, publically available information about faculty salaries in clinical laboratory science. Previously, such data have only been available by subscription and at prices that only larger institutions can afford. The data collected and analyzed here will serve as a talking point for faculty and administration on matters of salary within our field with regard to faculty degrees, job title, and specialty certification. This will also help the field of clinical laboratory science produce better and more equitable pay across institutions and among faculty with similar experience levels. However, we must not infer too much from the data. Other factors, such as faculty workload, vacation time, program size, and individual situations, also influence final salary determination. These areas require more study and conclusions cannot be made on how this may impact individual salary or specific situations, but is most useful when used in aggregate.

Unfortunately, the survey did not capture more data on certifications other than MLS/MT or MB certifications. One challenge the field of medical laboratory science faces is that its large amount of diversity in professional training and specialty areas can reduce advocacy for the whole field to one subspecialty. In future salary survey studies, we hope to have greater response rates that would enable us to perform more statistical analyses on subspecialty areas and extend this research further. More information about the roles that specialty, gender, regional location, and other factors have in determining salary can be studied as the present study generates more awareness about salaries and increases participation in future studies.

\section{ACKNOWLEDGEMENTS}

The authors would like to acknowledge Dr. Rod Mills (Austin Peay State University) and Dr. Teresa Nadder (Virginia Commonwealth University) for providing assistance with statistical analysis and helpful discussions regarding this study. Special thanks to the Scientific
Publications Department (University of Texas MD Anderson Cancer Center) for critical reading of the manuscript.

\section{REFERENCES}

1. Anderson, S.C., ed. Body of Knowledge: Clinical Laboratory Science Content Outline. McLean, VA: American Society for Clinical Laboratory Science; 2014.

2. Garcia E, Fisher PB. The American Society for Clinical Pathology's 2013 Wage Survey of Clinical Laboratories in the United States. Lab Medicine 2013;44:e97-e115. doi: 10.1309/LMWO4E34BQGHZXGM.

3. Eligibility for First Timers [Internet]. Kansas City (MO): American Association of Veterinary State Boards; c2015 [cited 2015 Aug. 19]. Available from https://www.aavsb.org/VTNE/ eligibility\%20for\%20first $\% 20$ timers/ .

4. Initial AART Certification and Registration [Internet]. St. Paul (MN): The American Registry of Radiologic Technologists; c2015 [cited 2015 Aug. 19]. Available from https://www.arrt. org/Certification.

5. The 2011 Uniform Licensure Requirements [Internet]. Chicago (IL): National Council on State Boards of Nursing; [Updated 2012 March, cited 2015 Aug. 19]. Available from https://www.ncsbn.org/12_ULR_table_adopted.pdf.

6. U.S. Certification [Internet]. Chicago (IL): American Society for Clinical Pathology Board of Certification; c2015 [cited 2015 Aug. 19]. Available from http://www.ascp.org/Board-ofCertification/GetCertified\#tabs-1.

7. Get Certified [Internet]. Rosemont (IL): American Medical Technologists; c 2015 [cited 2015 Aug. 19]. Available from http://www.americanmedtech.org/GetCertified.aspx .

8. Medical and Clinical Laboratory Technologists and Technicians. [Internet]. Bureau of Labor Statistics, U.S. Department of Labor. Occupational Outlook Handbook, 201415 Edition, [Updated 8 Jan. 2014, cited 2015 Aug. 19]. Available from http://www.bls.gov/ooh/healthcare/medicaland-clinical-laboratory-technologists-and-technicians.htm.

9. Institutional Profile Survey [Internet]. Washington (D.C): Association of Schools of Allied Health Professions. c2015 [cited 2015 Aug. 19]. Available from http://www.asahp.org/ memberssection/institutional-profile-survey/.

10. Faculty in Higher Education Salary Survey for the 2013 - 2014 Academic Year [Internet]. Knoxville (TN): College and University Professional Association for Human Resources. [Updated 2014 March, cited 2015 Aug. 19]. Available from http://www.cupahr.org/surveys/files/salary2014/FHE4-2014Executive-Summary.pdf.

11. 2010 Classification of Instructional Programs 2-Digit and 4Digit CIP Codes [Internet]. Knoxville (TN): College and University Professional Association for Human Resources. [cited 2015 Aug. 19]. Available from http://www.cupahr.org/ surveys/files/salary2015/FHE4-15-2-4-CIP-Codes.xls .

12. Scanlan, P.M. Letters. Lab Medicine 2011;42:442.doi: 10.1309/LMDCZLP51PA6SCLQ. 